\title{
UAV PHOTOGRAMMETRY AND HBIM FOR THE VIRTUAL RECONSTRUCTION OF HERITAGE
}

\author{
F. Carvajal-Ramírez ${ }^{1 *}$, P. Martínez-Carridondo ${ }^{3}$, L. Yero-Paneque ${ }^{2}$, F. Agüera-Vega ${ }^{1}$. \\ ${ }^{1}$ Department of Engineering, Mediterranean Research Center of Economics and Sustainable \\ Development (CIMEDES), University of Almeria, (Agrifood Campus of International Excellence, ceiA3). La Cañada de San \\ Urbano, s/n. 04120 Almería, Spain - (carvajal, faguera)@ual.es \\ ${ }^{2}$ MSc. Architect, Technological University of Havana, Havana, Cuba - lyp243@inlumine.ual.es \\ ${ }^{3}$ Peripheral Service of Research and Development based on Drones, University of Almeria, La Cañada de San Urbano, s/n. 04120 \\ Almeria, Spain-pmc824@ual.es
}

\section{Commission II, WG II/8}

KEY WORDS: UAV photogrammetry; HBIM; cultural heritage; virtual reconstruction; 3D modelling.

\begin{abstract}
:
Three-dimensional (3D) models have become a great source of data for the conservation, reconstruction, and documentation of emblematic buildings of cultural heritage. In this study, photogrammetry based on Unmanned Aerial Vehicles (UAVs) was applied to perform a photogrammetric survey of a dilapidated cultural heritage building. On the basis of this survey and the historical information gathered from the building, its virtual reconstruction has been carried out using a Historic Building Information Modeling (HBIM); applying realistic materials and textures in order to document it.
\end{abstract}

\section{INTRODUCTION}

The methods of digitization or 3D virtualization based on images, today, are a very useful technique in the area of cultural heritage; specifically related to the Unmanned Aerial Vehicles (UAVs), which represent an emerging and economic technology in the data collection of photogrammetric surveys; and can be equipped with high resolution cameras, obtaining nadiral images and oblique during low altitude flights with greater security for the operator. The use of oblique photographs improves the results obtained by Structure from Motion (SfM) Photogrammetry, by allowing the visualization of hidden details of the nadiral views (Aicardi et al., 2016), thus avoiding the use of terrestrial photographs.

The processing of these images with SfM algorithms can provide very accurate 3D models (Chatzistamatis, Kalaitzis, Chaidas, Chatzitheodorou, Papadopoulou, Tataris and Soulakellis, 2018), obtaining as a result a three-dimensional mesh model that can be used as a reference for the creation of a Building Information Modeling (BIM) model, whose methodology covers the design, construction and administration processes of a building's data throughout its life cycle (Merchán, Salamanca, Pérez, Moreno, 2018). Its implementation in patrimonial works depends on the irregularities of each building. Because of this, parametric objects created on BIM platforms can not be used; having to create new objects and own libraries, slowing down the modeling process. For this reason, new challenges arise in 3D digital modeling (Barazzetti et al., 2015), such as Historic Building Information Modeling (HBIM).

HBIM as a plug-in for BIM is a novel library of prototypes of parametric architectural objects; constructed from historical data and remote collection of survey data, using TLS or photogrammetry; to digitally model historic buildings (Capone and Lanzara, 2019; Dore and Murphy, 2012). More and more intervention works in the architectural heritage are based on an HBIM model based on the geometric information provided by the scanning and photogrammetry equipment (Dore, Murphy, and Dirix, 2017). The main objective of this study is to reconstruct virtually through an HBIM model, the Cortijo del Fraile, in Níjar, Almería, Spain; patrimonial work that is in a ruinous condition.

\section{CASE STUDY}

The Cortijo del Fraile (Fig.1), is a building built in the eighteenth century, located southeast of Níjar, Almería; inside the Natural Park of Cabo de Gata-Níjar. It is located on an estate of 730 hectares, in an arid landscape of volcanic lands and rising elevations towards the coast. The southwest and northeast UTM coordinates (Zone 30, ETRS89) of the study area are (582385, $4080340)$ and $(582515,4080470)$, respectively.

The Cortijo del Fraile is famous for the crime that occurred in its vicinity in 1928, the so-called "Crime of Nijar" (Torres Flores and Roldán Molina, 2018), whose protagonist, Francisca Cañadas (Luis Antonio de Villena, 1998), lived in the surroundings all his life. This real story inspired Federico García Lorca for the plot of his tragedy "Bodas de Sangre" (1931); also the dramatic and poetic vision "Puñal de Claveles" (1931) by Almeria writer Carmen de Burgos (Cabañas Alamán, 2009). Bearing in mind that little information is available regarding the original image of the Cortijo (Cortijo del Fraile, 2019), the graphic proposal of films like "The Good, the bad, the ugly" and others inspired by Sergio Leone in the sixties, show images of their original architecture. The Cortijo del Fraile was declared "Property of Cultural Interest" and inscribed in the General Catalog of the Andalusian Historical Heritage, with the typology of "Historic Site" (DECRETO 44/2011, de 22 de Febrero).

\section{* Corresponding author}




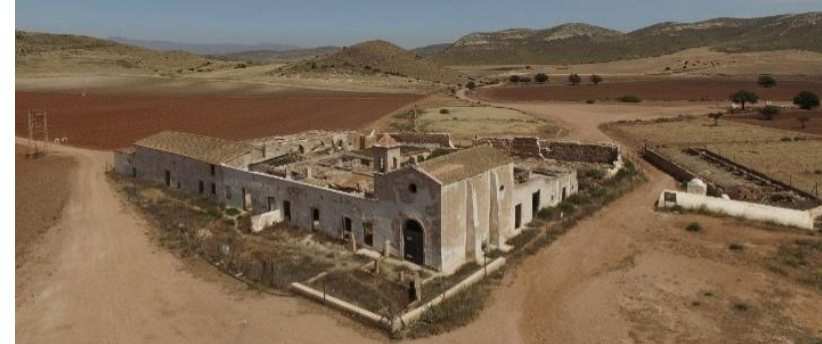

Fig. 1. Actual image of the main façade of Cortijo del Fraile

\subsection{Description of the building}

The built-up area, as shown in figure 2, has a trapezoidal-shaped floor plan, with a plot area of $3,013 \mathrm{~m}^{2}$ and a built-up area (main house, sharecroppers and shepherd, chapel, stables, and corrals) is estimated at $1,835 \mathrm{~m} 2$. The building responds to the typology of "Vernacular Architecture" (Cortijo del Fraile, Lista Roja del Patrimonio, 2012), where several units are distributed on a single floor around a central courtyard. The nucleus consists of housing for the owners, chapel, houses of the sharecroppers and the shepherd; central courtyard, corrals, barns, pigsties, wells, and cisterns.

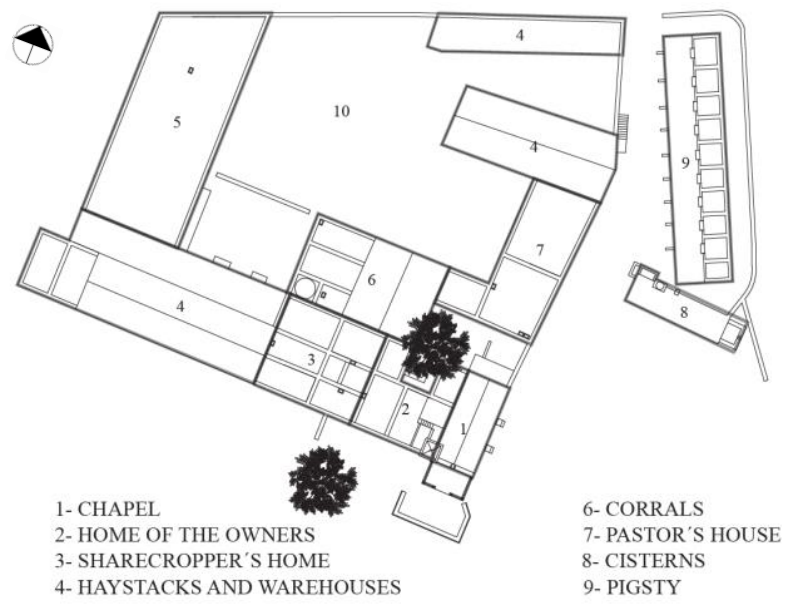

Fig. 2. General scheme of the Cortijo del Fraile.

The Cortijo del Fraile is a typical example of scattered buildings, on one level, with buildings of solid character, flat roofs compartmentalized by the vertical extension of the load-bearing walls and where the chimneys of the various kilns stand out as isolated elements in the predominant horizontality of the whole. The Cortijo is considered one of the best examples of large houses, combining the use of housing with other dependencies of agricultural work; leading to a complex building.

The chapel has a rectangular floor plan and a gable roof with flat tile, standing out for its volume in the whole, having a small bell tower with a square base of bricks and a hipped roof with a flat tile. The interior of the chapel has a barrel vault, with pointed arches resting on pilasters, and an altarpiece in the presbytery. Under the altar, there is a funerary crypt with twelve niches and on the ground the entrance to an underground chamber. The vertical structure of the building is formed by stone masonry load-bearing walls with mud, plaster or lime as binders. At the same time, many of the load-bearing walls are made up of semicircular arches, which are not usual in the immediate constructions of the site. The roofs are generally flat, with the exception of the corrals linked to the dwelling of the sharecropper and the haystack, which have a gable roof made of Arabic tiles. After its definitive abandonment in the eighties, the current state of construction is one of ruin (Fig. 3), having been in a state of abandonment for more than 40 years and in constant danger of collapse. Today, it is the private property of a company that exploits the farm and its wells for ecological agricultural production in the open air.

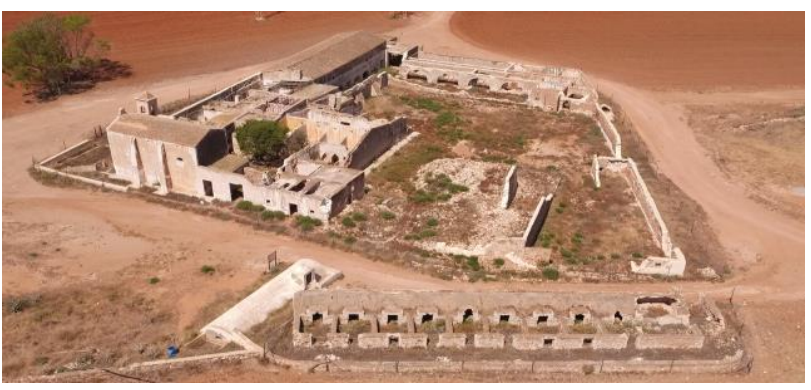

Fig. 3. Current state of ruin of the facilities of Cortijo del Fraile

\section{APPLICATION OF UAV TECHNOLOGY}

To perform the photogrammetric survey; firstly, 8 targets were placed around the building (Fig. 4), due to the inability to access the interior to be able to georeference Ground Control Points $(G C P s)$ and evaluating the accuracy of the photogrammetric project Checkpoints (CPs). The targets consisted of A3 size (420 $\times 297 \mathrm{~mm}$ ) red paper on which were two black squares. The three-dimensional coordinates of these points were measured with a Global Navigation Satellite System (GNSS) receiver working in Post Processed Kinematic (PPK) mode, with the base situated at a point near the main facade of the building. Horizontal coordinates are referred to as UTM Zone 30N (European Terrestrial Reference System 1989, ETRS89) and the elevation is referred to the Mean Sea Level (MSL) using the EGM08 geoid model. The GNSS base receivers were from the Trimble R6 system. Once the support points were placed, the photographic shot was taken with a UAV DJI MATRICE 600 PRO with six rotors; was equipped with a digital camera with a lens with a fixed focal length of $15 \mathrm{~mm}$ and diagonal FOV of 72 degrees. The resolution of the camera sensor was 16 megapixels $(4608 \times 3456)$.

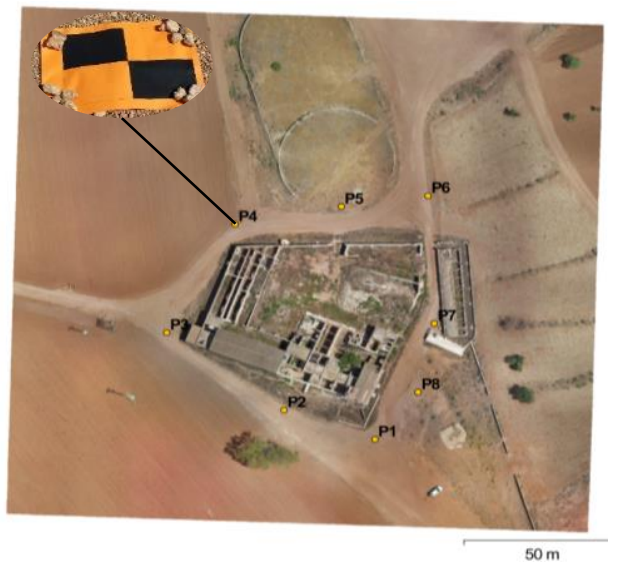

Fig. 4. Distribution of GCPs for the georeferencing of the photogrammetric project, overlapped to orthoimage obtained from photogrammetric project

Two flights were made; the first at a height of $50 \mathrm{~m}$ above ground level, with an autopilot using the DJI GS Pro (C) application to obtain nadiral photographs. The flight plan consisted of 11 
passes. The camera was triggered every two seconds, the flight speed was set to obtain forward, and side overlaps of $80 \%$ and $65 \%$, respectively. The second flight was established at a height of $15 \mathrm{~m}$ above the ground level because the height of the building is $12 \mathrm{~m}$. This flight was made manually to obtain oblique photographs of the four facades and the interior of the building. Figure 5 shows the locations of the camera and the overlapping of the images, where the blue color indicates that the point of the terrain appears in more than nine photographs. A total of 623 photographs were taken, used to perform the photogrammetric process. In table 1 , the details of the cameras are shown.

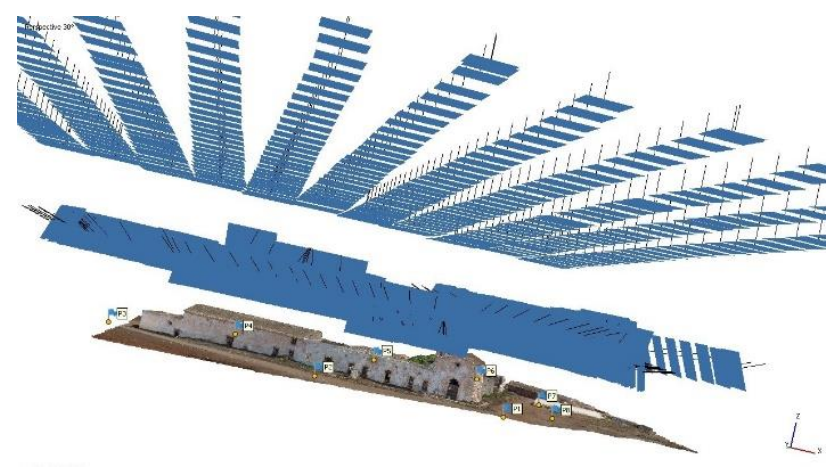

Fig. 5. Camera locations grouped in two flying heights

\begin{tabular}{|l|l|}
\hline Number of images & 623 \\
\hline Flying altitude & $49.2 \mathrm{~m}$ \\
\hline Ground resolution: & $1.16 \mathrm{~cm} / \mathrm{pix}$ \\
\hline Coverage area: & $3.49 \mathrm{e}+04 \mathrm{sq} \mathrm{m}$ \\
\hline Camera stations: & 623 \\
\hline Tie points: & 298,321 \\
\hline Projections: & $2,216,716$ \\
\hline Reprojection error: & $2.3 \mathrm{pix}$ \\
\hline
\end{tabular}

Table 1. Detail of cameras

\subsection{Photogrammetric process}

The photogrammetric process was carried out using the software package Agisoft PhotoScan Professional (c) version 1.2.4.2399 (Agisoft PhotoScan, 2015). This photogrammetric software is based on creating high-quality 3D models from images, using $3 D$ Multivision reconstruction technology (Furukawa and Ponce, 2010) and the SfM algorithm (Javernick, Brasington, and Caruso, 2014); and it has been used because it has been proven to outperform other software applications in terms of accuracy (Sona, Pinto, Pagliari, Passoni and Gini, 2014). The software processing part of selecting the nadiral and oblique images that are going to be used in the process. Agisoft PhotoScan is able to adjust the calibration parameters of the camera automatically during the calculation of the orientations of the images, starting from the initial values extracted from the image data. Then the images are aligned by calculating the internal orientation and a scattered 3D point cloud with correspondence between images. In the process of alignment, the program uses several algorithms that detect the points and obtain the orientation and position of the images. In this study, the model has been georeferenced indirectly through the topographic survey carried out with the Trimble R6 GNSS. Then you get the cloud of dense points that serves as the basis for the construction of the three-dimensional mesh. From the high density of points created, the mesh/network of interpolated triangles is produced to subsequently generate the final texturized model. Then I applied to texture to the mesh obtained in the previous step. Finally, the orthophoto is exported and a DSM grid can be generated from the cloud point. The dense point cloud can also be exported in (*.the) format, as well as the mesh in $(* . o b j),(* .3 d s)$ or $(* . d x f)$ format. The bundle adjustment is carried out at least three GCPs, but more accurate results are obtained if more GCPs are used, and it is recommended that they are used to obtain optimal accuracy (Agüera-Vega, Carvajal-Ramírez, and Martínez -Carricondo, 2017).

\section{APPLICATION OF THE HBIM METHODOLOGY}

Virtual reconstruction involves the attempt of visual recovery, from a virtual model, at a specific moment of construction or object manufactured by the human being in the past based on the existing physical evidence (Carta de Londres, 2009). HBIM is the possible solution for the three-dimensional parametric representation, which allows the user to draw models and manage data on historical architectural elements, within a common software environment (Icon.Net Pty Ltd 2009), being the data exchange format Industry Foundation Classes (IFC) the most used, since it is an open and neutral standard maintained by BuildingSMART®. BIM modeling was carried out using the software Autodesk Revit (C) 2019, today, one of the most used BIM software, which contains several dimensions $4 D$ (Time), $5 D$ (Cost), 6D (Sustainability) and 7D (Management and Maintenance) in building models, achieving interoperability through the use of different programs and several disciplines (Tommasi and Achille, 2017). In this study, the modeling procedure performed (Fig. 6), part of the data captured using the UAV-Photogrammetry technology, described in the previous section.

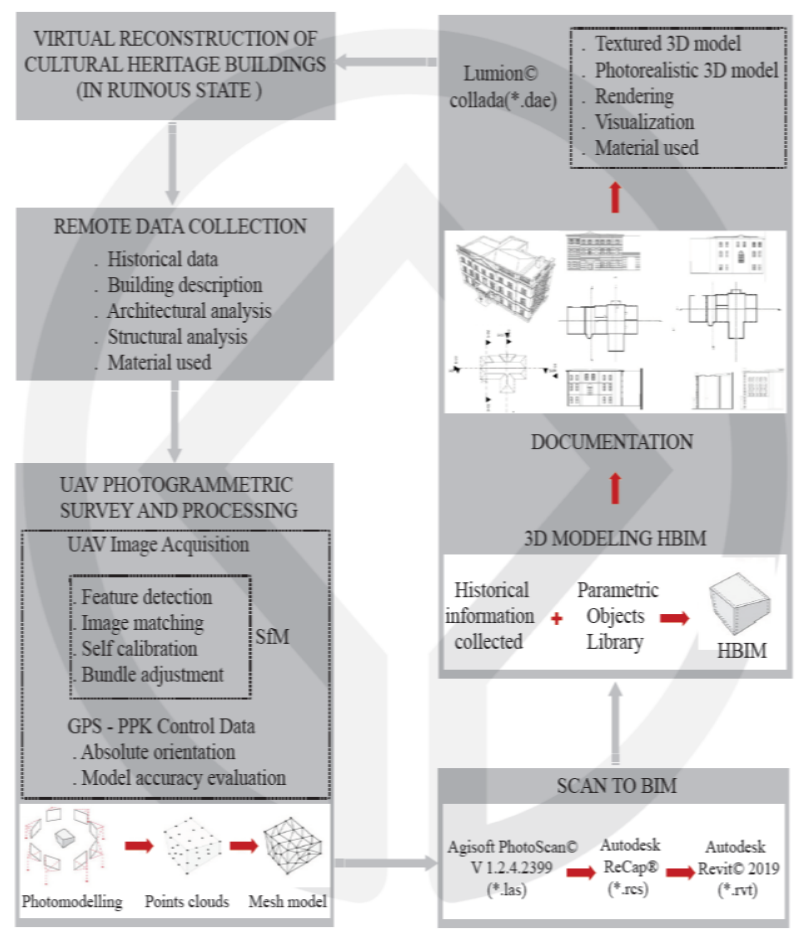

Fig. 6. Modeling procedure performed. 


\subsection{Scan to BIM}

The term Scan to BIM incorporates the exploration process, by scanning data in the form of Point Cloud Data $(P C D)$ point clouds that contain geospatial information about the building and its surroundings (Hajian and Becerik-Gerber, 2010). Revit ${ }^{\circledR}$ can link the point cloud from its own interface or through the Autodesk ReCap ${ }^{\circledR}$ application with the format (*.las) that stores the color information obtained from the images, allowing their visualization. The procedure that has been used for Scan to BIM is: PhotoScan (*.las) -> ReCap (*.rcs) -> Revit (*.rvt).

Based on the scanty historical information collected from the building, as archive images of films showing their original architecture, historical parametric objects can be reconstructed. The parametric character of Revit ${ }^{\circ}$ allows for a certain constructive element; for example, in this study: the Tuscan portico attached to the interior of the chapel (Fig. 7a); take as a base created objects such as the entablature, the capital, the shaft and the base of Tuscan order, to modify the values of their dimensions according to the scale; infinite combinations can be obtained depending on the alphanumeric parameters.

This process would be applicable for all created historical parametric objects that make up the model (Fig. 7). Another of the parametric objects created is the barrel vault inside the chapel (Fig. 7b), which is made of reinforced concrete and has two semicircular arches, which rest on pilasters by the corresponding abutments. a)

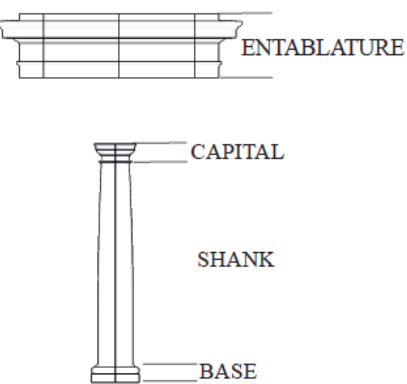

b)

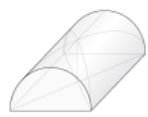

BASIC FORM OF THE VAULT

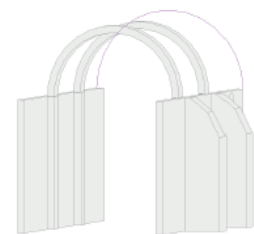

TRANSVERSE ARCHES BARREL VAULT

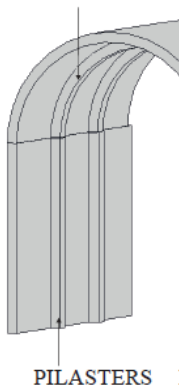

PILASTERS

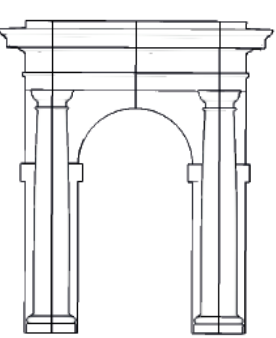

TUSCAN PORTICO c)

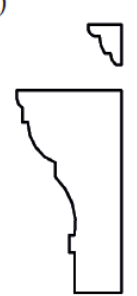

BASIC FORM

d)

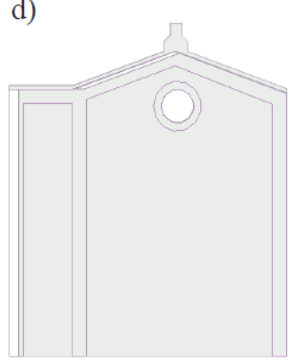

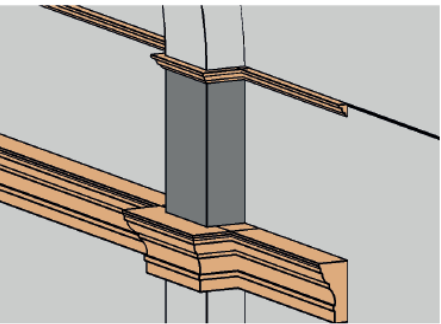

CLASSIC MOLDING

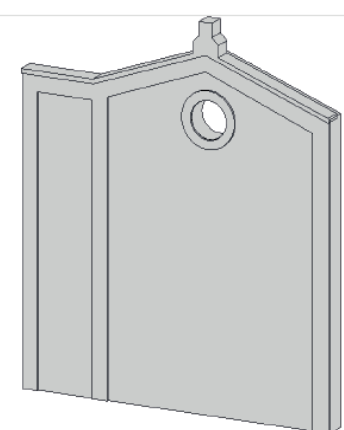

Fig. 7. Parametric objects library; c) set of moldings (listel, strips, half bocel and caveto) that are basic elements of classical architecture; d) Striped pediment where the upper part is interrupted by an ornamental motif
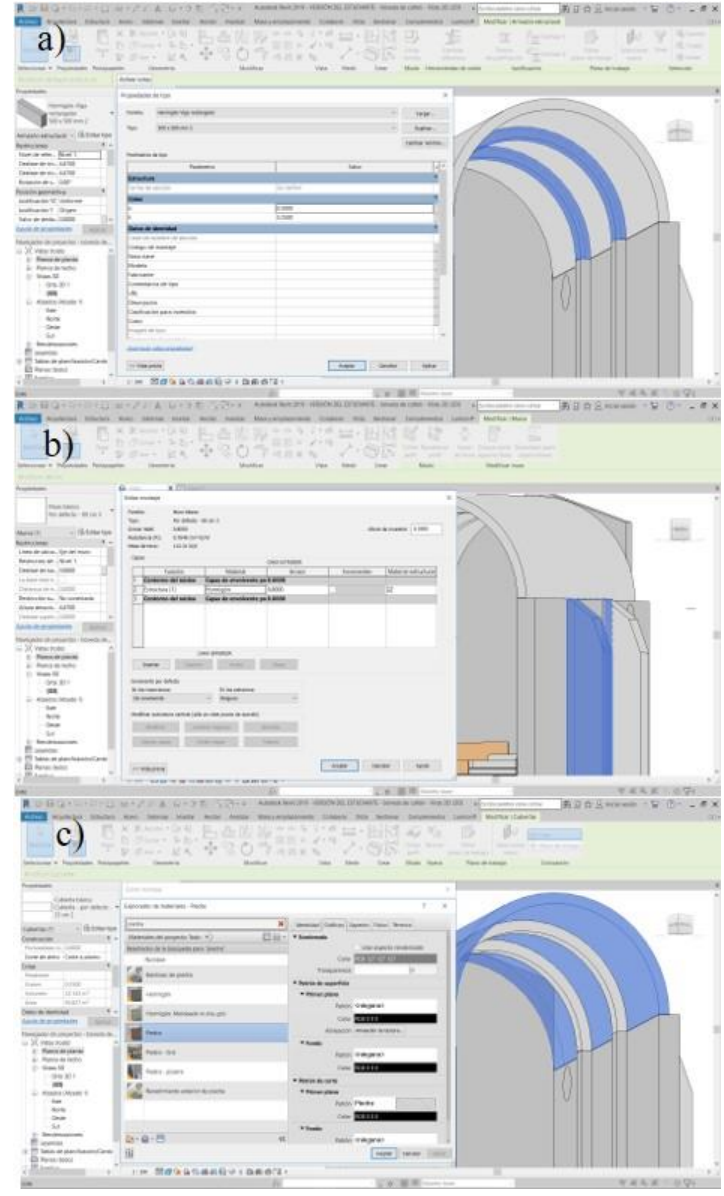

Fig. 8. Metadata. Barrel vault; a) geometric data of the arcs fajones; b) characteristics of the structural elements of the abutments, such as the resistance of the materials; c) characteristics of the materials of the barrel vault 


\subsection{Modeling Process}

Starting from the three-dimensional mesh, 3D modeling is done manually of all the elements that make up the model; because Revit@, as a BIM software, does not have an automatic geometry recognition option. The most recent scientific literature states that great efforts are being made in automatic recognition to generate $3 \mathrm{D}$ geometries, but this lacks the valid details to be applied in the heritage area (Dore and Murphy, 2017). The complete modeling process was carried out in approximately 48 hours of work. The information received in Revit ${ }^{\circledR}$ is thousands of colorimetric points of information that show details of the property, such as, for example if a wall has an inclination. In this way it is possible to visualize the cloud of dense points to use as a guide to establishing the levels in section, the axes in plant (Chiabrando, Lo Turco, and Rinaudo, 2017, Oreni, Karimi, and Barazzetti, 2017, Rodríguez-Moreno et al., 2018), and later, modeling the entire building.

To obtain photorealistic images, it is necessary to add materials and textures to the 3D model. Revit is not software designed to render, on the other hand, Lumion () is a software-based on video game rendering engines that is revolutionizing the current outlook. Both software has data exchange format; therefore, the $3 \mathrm{D}$ model can be exported from Revit ${ }^{\circledR}$ to Lumion (ㄷ to add materials and textures (Meini, Felice, and Petrella, 2018) and perform the rendering process. The best way to export them is through "Lumion Plug-in for Revit". The plug-in includes two functionalities: exporter for LiveSync which allows visualizing the model in real-time, and also export it as a type file Collada ${ }^{*}$ .dae) of Revit and load or reload it constantly in Lumion.

\section{RESULTS}

\subsection{Accuracy of the photogrammetric project}

Table 2 shows the precision obtained, for each of the GCPs, in the adjustment of the photogrammetric block. By not having more additional points Checkpoints (CPs) to evaluate the accuracy of the 3D model obtained, this was obtained as indicated in (Sanz-Ablanedo et al., 2018). In this way, the accuracy of the model can be estimated based on the precision obtained during the photogrammetric block adjustment. Thus, in our study, a total of 8 GCPs and 330 zenith photographs were used, so the number of GCPs per 100 photos is around 2.5, which shows an overestimation of the accuracy of the block adjustment with respect to the of the factor 3.6 model. Therefore, in our study, we can estimate that the 3D model was obtained with an approximate precision of $0.36 \mathrm{~m}$. In figure 4 , the orthophoto generated as a result of the photogrammetric process is observed.

On the other hand, (Grenzdörffer, Naumann, Niemeyer, and Frank, 2015) in their experiment, combined the use of laser scanners and nadiral and oblique images obtained by UAV, resulting in differences between 2.5 and $8.8 \mathrm{~cm}$ in the point clouds. They came to the conclusion that UAVs are an excellent tool for those places that can not be accessed with a laser scanner, but that in some cases may require the use of terrestrial photographs for areas adjacent to the ground. In our study, it was not necessary to use terrestrial photographs, due to the use of oblique low-altitude aerial photographs $(<15 \mathrm{~m})$ with different inclination angles. This has been possible due to the peculiarities of the building studied since there are no prominent projections along the façade, and the ability of the UAV to move along all the elements of the building.

\begin{tabular}{|l|l|l|l|l|}
\hline Label & XY error & $\mathbf{Z}$ error & Error (m) & Error \\
$(\mathbf{m})$ & $(\mathbf{m})$ & & pix9 \\
\hline P1 & 0.0759695 & 0.039759 & 0.0857447 & 0.723 \\
\hline P2 & 0.024946 & 0.0360585 & 0.0438465 & 0.548 \\
\hline P3 & 0.0458986 & - & 0.103348 & 0.603 \\
\hline P4 & 0.0634247 & 0.0416442 & 0.0758745 & 0.623 \\
\hline P5 & 0.0731339 & 0.102679 & 0.126062 & 0.802 \\
\hline P6 & 0.102097 & - & 0.139969 & 0.756 \\
\hline P7 & 0.0430949 & 0.0131652 & 0.045061 & 0.507 \\
\hline P8 & 0.148894 & -0.045183 & 0.155598 & 0.581 \\
\hline Total & $\mathbf{0 . 0 8 0 8 7 1 7}$ & $\mathbf{0 . 0 6 6 2 5 2 2}$ & $\mathbf{0 . 1 0 4 5 4 5}$ & $\mathbf{0 . 6 2 6}$ \\
\hline
\end{tabular}

Table 2. Accuracy obtained on each GCP during photogrammetric bundle adjustment

Figure 9 shows the point cloud obtained by UAV photogrammetry using Agisoft PhotoScan, where the point cloud had a total of $27,046,199$ points. The mesh obtained had a total of $1,801,780$ faces and 901.504 vertices.

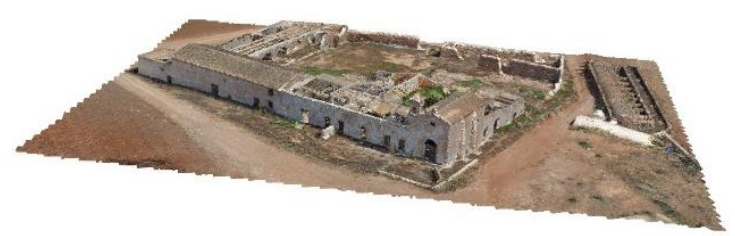

Fig. 9. Dense point cloud obtained from the photogrammetric project

\subsection{Accuracy of the HBIM model}

Each of the parametric objects created to develop the HBIM model must be validated by measuring the distances between the mesh of the photogrammetric model and the mesh of the parametric object created. Due to this, the parametric object must be exported from Revit in format $(* . f b x)$ and the photogrammetric model must be exported from Agisoft in format (* .obj). Both files must be imported from CloudCompare (Girardeau-Montaut, 2017), where you can use the "Cloud to Mesh Distance" command to calculate the distance between the parametric object created in Revit and the model created in Agisoft. In the absence of a criterion adopted by the scientific literature for the validation of a parametric object (Adami, Scala, and Spezzoni, 2017), in this research, the criterion has been to obtain an average difference of around 0 (between $-0.05 \mathrm{~m}$ and $0.05) . \mathrm{m}$ ) and a standard deviation of less than $0.10 \mathrm{~m}$. 
Figure 10 shows the HBIM model realized in Revit, which coincides in position and dimensions with the real element, so that, if a detailed study of it is wanted, this could be the basis. From the 3D model with its associated metadata, the planimetry (planes, sections, and elevations) was obtained; as well as the calculation memories.

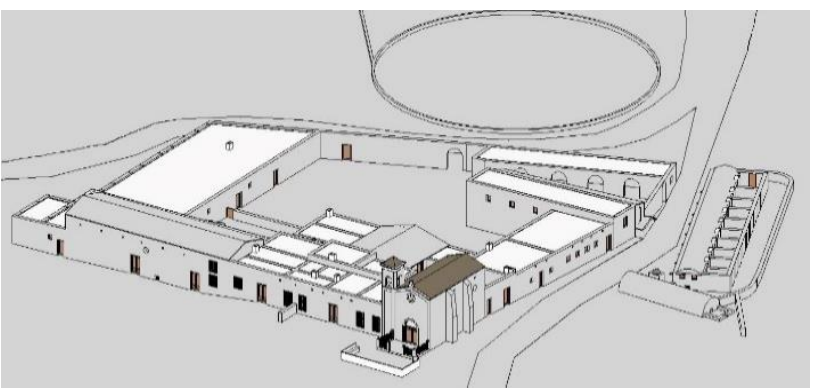

Fig.10. HBIM model of the building made in Revit

Figure 11 shows some of the representations obtained with Lumion (C) of the 3D model of the virtual reconstruction of Cortijo del Fraile, with the aim of achieving a photorealistic finish for conservation, archiving and documentation purposes.
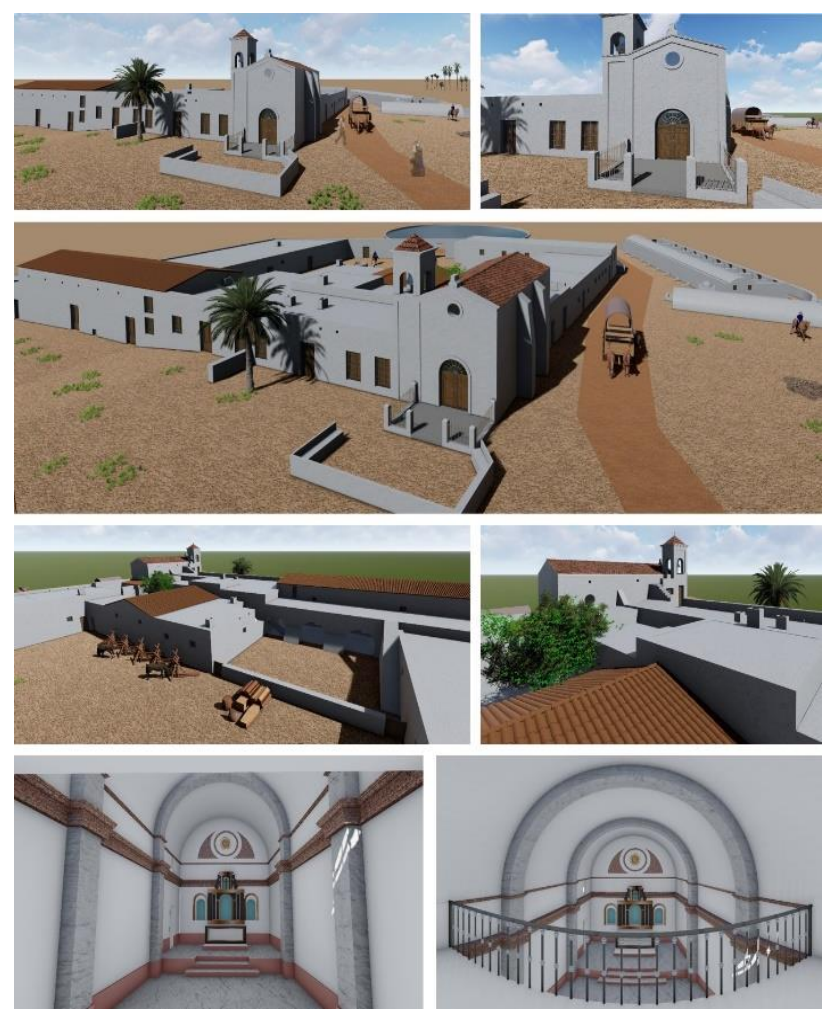

Figure 11. Renders obtained with Lumion @ $@$ software

Several authors have used the HBIM methodology to model buildings of cultural heritage. Specifically, (Oreni et al., 2017) developed an HBIM model to represent The Ice House of Filarete's Ospedale Maggiore in Milan (Italy). For this, they used two different parametric modeling tools, Revitß, and ArchiCAD®. The study showed the limitations and advantages in the workflow of each of them but concluded that the HBIM process allowed the integration of documented historical data with the existing physical state, in order to obtain a baseline for preventive maintenance, monitoring, and future conservation. It is, therefore, an ideal tool also for virtual reconstruction in those cases in which the current state is weakened or in a state of ruin, as has been done in this study. (Biagini, Capone, Donato, and Facchini, 2016) applied the HBIM modeling to the SS. Nome di Maria church in Mantua (Italy) concluding that this methodology allows representing the old building, the design ideas and the intervention phases, all from the parametric modeling based on a digital point cloud of the current state. (R. Quattrini, Malinverni, Clini, Nespeca, and Orlietti, 2015) developed an HBIM of the Church of Santa Maria at Portonovo, an abbey from the Romanesque period emphasizing that this model serves as the basis for a set of data for all disciplines, in particular for restoration and conservation.

On the other hand, (Karachaliou, Georgiou, Psaltis, and Stylianidis, 2019) developed an HBIM model in the Revit ${ }^{\circledR}$ software of the "Averof's Museum of Neohellenic art" located in Metsovo, Greece, using the orthoimages of the facades produced with photogrammetry processes UAV generated in PhotoScan and exterior and interior designs of the building, as has also been shown in this work. In addition, they made measurements in situ of the interior places of the building; instead, it is this study, because the Cortijo del Fraile is totally in ruins and access to the interior is prohibited; most of the inside information was captured from the flight with the drone, since most of the spaces had the roof collapsed; and also, with the support of data found together with archive photographs; obtaining the same results in terms of accuracy and quality of the information.

\section{CONCLUSIONS}

The cloud of points turns out to be the best possible base for the survey and subsequent modeling of patrimonial buildings in dilapidated condition. It is necessary to complement this technology with a thorough and exhaustive study of the existing historical document that provides information about the original geometry and architecture. Recent experimentation in the field (Bruno and Roncella, 2018) indicates that there is a lot to overcome in terms of costs, training and processing times, the use of HBIM in the cultural heritage field is a good solution and a potential for more coordinated and efficient management and preservation (Karachaliou, Georgiou, Psaltis, and Stylianidis, 2019).

Although sometimes this fundamental premise is left aside, we believe that adequate graphic documentation can be one of the most effective means for the conservation of cultural heritage, thanks to the relatively small resources that are needed and the high amount of information recorded and safeguarded. In an extreme case, a building could disappear, leaving its material cultural values conveniently preserved through complete graphic documentation (Talaverano, 2014). This study has shown that it is possible to successfully implement this method of work and obtain, therefore, a reconstructed model that allows the visualization, as well as the archiving and recording of the documentation with a view to future restoration and conservation projects.

The result of the HBIM model achieved in this work allows obtaining data from different materials and construction techniques, as well as its zoning within the building, to perform stratification and chronological studies depending on the materials and techniques used. Also, pathologies can be detected, especially for the calculation of the deformations of a constructive element; installing deformation control sensors that 
will send the information to the HBIM system, taking information on this type of pathologies in real-time. The control of dampness by means of a sensor system is also very useful, especially in large walls that are affected by different types of humidity. On the other hand, by means of the different construction phases of the project, the different historical phases of the project can be obtained. In addition, you can manage the entire project, like any BIM system, which allows the preparation of different projects, as well as implement it as a maintenance tool, especially for economic calculation.

\section{REFERENCES}

Adami, A., Scala, B., and Spezzoni, A. 2017. Modelling and accuracy in a bim environment for planned conservation: The apartment of troia of Giulio Romano. In: The International Archives of the Photogrammetry, Remote Sensing and Spatial Information Sciencess, Vol. XXII, pp. 17-23.

https://doi.org/10.5194/isprs-archives-XLII-2-W3-17-2017

Agüera-Vega, F., Carvajal-Ramírez, F., and MartínezCarricondo, P. 2017. Assessment of photogrammetric mapping accuracy based on variation ground control points number using unmanned aerial vehicle. Measurement, 98, pp. 221-227. https://doi.org/10.1016/j.measurement.2016.12.002

Aicardi, I., Chiabrando, F., Grasso, N., Lingua, A. M., Noardo, F., and Spanó, A. 2016. UAV photogrammetry with oblique images: First analysis on data acquisition and processing. In: The International Archives of the Photogrammetry, Remote Sensing and Spatial Information Sciences, Vol. XII, pp. 835-842. https://doi.org/10.5194/isprsarchives-XLI-B1-835-2016

Barazzetti, L., Banfi, F., Brumana, R., Gusmeroli, G., Previtali, M., and Schiantarelli, G. 2015. Cloud-to-BIM-to-FEM: Structural simulation with accurate historic BIM from laser scans. Simulation Modelling Practice and Theory, 57, 71-87. https://doi.org/10.1016/j.simpat.2015.06.004

Biagini, C., Capone, P., Donato, V., and Facchini, N. 2016 Towards the BIM implementation for historical building restoration sites. Automation in Construction, 71, 74-86. https://doi.org/10.1016/j.autcon.2016.03.003

Bruno, N. and Roncella, R., 2018. A restoration oriented HBIM system for cultural heritage documentation: the case study of Parma cathedral. In: The International Archives of Photogrammetry, Remote Sensing and Spatial Information Science, Vol. XLII-2, pp. 171-178.

Capone, M. and Lanzara, E. 2019. Scan-to BIM and Ideal Model HBIM: Parametric tools to study domes geometry. In: The International Archives of the Photogrammetry, Remote Sensing and Spatial Information Sciences, Vol. XLII-2, pp. 219-226. https://doi.org/10.5194/isprs-archives-xlii-2-w9-219-2019

Cortijo del Fraile. 2019. Retrieved March 25, 2019.

https://guiadigital.iaph.es/bien/inmueble/23046

Cortijo del Fraile - Lista Roja del Patrimonio. 2012. Retrieved March 25, 2019. https://listarojapatrimonio.org/ficha/cortijo-delfraile/

Chatzistamatis, S., Kalaitzis, P., Chaidas, K., Chatzitheodorou, C., Papadopoulou, E. E.,Tataris, G., and Soulakellis, N. 2018.
Fusion of TLS and UAV photogrammetry data for postearthquake 3D modeling of a cultural heritage Church. In: The International Archives of the Photogrammetry, Remote Sensing and Spatial Information Sciences. Vol. XLII-3/W4, pp. 143-150 https://doi.org/10.5194/isprs-archives-XLII-3-W4-1432018

Chiabrando, F., Lo Turco, M., and Rinaudo, F. 2017. Modeling the decay in an HBIM starting from $3 \mathrm{~d}$ point clouds. A followed approach for cultural heritage knowledge. In: The International Archives of the Photogrammetry, Remote Sensing and Spatial Information Sciences, Vol. XLII-2/W5, pp. 605-612. https://doi.org/10.5194/isprs-archives-XLII-2-W5-605-2017

DECRETO 44/2011, de 22 de febrero; BOJA (Boletín Oficial de la Junta de Andalucía) no 42 de 02/03/2011. Retrieved March 25, 2019. https://www.juntadeandalucia.es/boja/2011/42/51

Dore, C. and Murphy, M. 2012. Integration of Historic Building Information Modeling (HBIM) and 3D GIS for recording and managing cultural heritage sites. In: Proceedings of the 2012 18th International Conference on Virtual Systems and Multimedia, Vol. VSMM 2012: Virtual Systems in the Information Society, pp. 369-376. https://doi.org/10.1109/VSMM.2012.6365947

Dore, C. and Murphy, M. 2017. Current state of the art historic building information modelling. In: The International Archives of the Photogrammetry, Remote Sensing and Spatial Information Sciences. Vol XLII-2/W5. Pp. 185-203. https://doi.org/10.5194/isprsarchives-XLII-2-W5-185-2017

Furukawa, Y., and Ponce, J. 2010. Accurate, dense, and robust multiview stereopsis. IEEE Transactions on Pattern Analysis and Machine Intelligence, Vol. 32(8), pp. 1362-1376. https://doi.org/10.1109/TPAMI.2009.161

Grenzdörffer, G. J., Naumann, M., Niemeyer, F., and Frank, A. 2015. Symbiosis of UAS photogrammetry and TLS for surveying and 3D modeling of cultural heritage monuments-a case study about the cathedral of St. Nicholas in the city of Greifswald. In: The International Archives of the Photogrammetry, Remote Sensing and Spatial Information Sciences, Vol 40(1W4), pp. 9196. https://doi.org/10.5194/isprsarchives-XL-1-W4-91-2015

Hamid Hajian, Burcin Becerik-Gerber. 2010. Scan to BIM: Factors Affecting Operational and Computational Errors and Productivity Loss. In: 27th International Symposium on Automation and Robotics in Construction. Vol. ISARC 2010, pp. 265-272. http://www.irbnet.de/daten/iconda/CIB_DC23919.pdf

Javernick, L., Brasington, J., and Caruso, B. 2014. Modeling the topography of shallow braided rivers using Structure-fromMotion photogrammetry. Geomorphology, Vol 213, pp. 166182. https://doi.org/10.1016/j.geomorph.2014.01.006

Karachaliou, E., Georgiou, E., Psaltis, D., and Stylianidis, E. 2019. UAV for Mapping Historic Buildings: from 3D modelling to BIM. In: The International Archives of the Photogrammetry, Remote Sensing and Spatial Information Sciences. Vol. XLII2/W9, pp. 397-402, https://doi.org/10.5194/isprs-archives-xlii-2w9-397-2019

Lopéz, M., Bendicho M., and Grande, A. 2011. Hacia una Carta Internacional de Arqueología Virtual. El Borrador SEAV. Virtual Archaeology Review. Vol. 2(4), pp. 71-75. 
Luis Antonio de Villena, 1988. Retrieved March 25, 2019 http://www.historiamujeres.es/vidas/canadas.html

Martín Talaverano, R., 2014. Documentación gráfica de edificios históricos: principios, aplicaciones y perspectivas, Arqueología de la Arquitectura, Vol. 11, doi.org/10.3989/arq.arqt.2014.014

Meini, M., Felice, G. Di, and Petrella, M. 2018. Geotourism Perspectives for Transhumance Routes. Analysis, Requalification and Virtual Tools for the Geoconservation Management of the Drove Roads in Southern Italy, Goesciences, 8(19) pp. 1-32. https://doi.org/10.3390/geosciences8100368

Merchán, P., Salamanca, S., Merchán, M. J., Pérez, E., and Moreno, D. 2018. Pasado, Presente Y Futuro De Los HBIM (Heritage/Historic Building Information Models). In Actas de las XXXIX Jornadas de Automática, pp. 1077-1084. http://hdl.handle.net/10662/8884

Oreni, D., Karimi, G., and Barazzetti, L. 2017. Applying BIM to built heritage with complex shapes: The Ice House of Filarete's Ospedale Maggiore in Milan, Italy. In: The International Archives of the Photogrammetry, Remote Sensing and Spatial Information Sciences, Vol. 42(2W5), pp. 553-560. https://doi.org/10.5194/isprs-archives-XLII-2-W5-553-2017

Quattrini, R., Malinverni, E., Clini, P., Nespeca., R and Orlietti, E. 2015. From TLS to HBIM. High quality semantically-aware 3D modelling of complex architecture. In: The International Archives of the Photogrammetry, Remote Sensing and Spatial Information Sciences, Vol. XL-5/W4, pp. 367-374 https://doi:10.5194/isprsarchives-XL-5-W4-367-2015

Cabañas, R. 2009. Puñal de claveles, de Carmen de Burgos, y Bodas de Sangre, de Federico García Lorca: La frustración y la naturaleza (paralelismos y contrastes). Estudios Humanísticos. Filología 31, pág. 55-85

Rodríguez-Moreno, C., Reinoso-Gordo, J. F., Rivas-López, E., Gómez-Blanco, A., Ariza-López, F. J., and Ariza-López, I. 2018. From point cloud to BIM: an integrated workflow for documentation, research and modelling of architectural heritage. Survey Review, 50, pp. 212-231. https://doi.org/10.1080/00396265.2016.1259719

Sona, G., Pinto, L., Pagliari, D., Passoni, D., and Gini, R., 2014. Experimental analysis of different software packages for orientation and digital surface modelling from UAV images. Earth Science Informatics, 7(2), pp. 97-107. https://doi.org/10.1007/s12145-013-0142-2

Tommasi, C., and Achille, C., 2017. Interoperability matter: Levels of data sharing, starting from a 3D Information Modelling. In: The International Archives of the Photogrammetry, Remote Sensing and Spatial Information Sciences, Vol. XLII-2/W3, pp. 623-630. https://doi.org/10.5194/isprs-archives-XLII-2-W3-623-2017

Torres Flores, A., and Roldán Molina, Á. M. 2018. ¡Llévame contigo, ahora o nunca! Arráez Editores, Almería. 